$$
\begin{aligned}
& \text { Whin Schnit } \\
& 4-24-75
\end{aligned}
$$

THE GEORGE FISHER BAKER NON-RESIDENT LECTURESHIP IN CHEMISTRY AT CORNELL UNIVERSITY

BORANES IN ORGANIC CHEMISTRY

By Herbert C. Brown 
Digitized by the Internet Archive in 2018 with funding from Kahle/Austin Foundation 


\section{BORANES IN}

\section{ORGANIC CHEMISTRY}

\section{by HERBERT C. BROWN}

R. B. Wetherill Research Professor

Purdue University

Cornell University Press | ithaca and London 
Copyright (C) 1972 by Cornell University

All rights reserved. Except for brief quotations in a review, this book, or parts thereof, must not be reproduced in any form without permission in writing from the publisher. For information address Cornell University Press, 124 Roberts Place, Ithaca, New York 14850.

First published 1972 by Cornell University Press. Published in the United Kingdom by Cornell University Press Ltd., 2-4 Brook Street, London W7Y $1 A A$.

International Standard Book Number 0-8014-0681-1 Library of Congress Catalog Card Number 79-165516

COMPOSED BY KINGSPORT PRESS, INC. PRINTED IN THE UNITED STATES OF AMERICA BY VAIL-BALLOU PRESS, INC. Librarians: Library of Congress cataloging information appears on the last page of the book. 
TO MY WIFE-

who made the writing of my previous book a pleasure and the writing of the present one a necessity 
